\title{
Mechanism of Action of Blocking Immunoglobulin G for Neisseria gonorrhoeae
}

\author{
K. A. Joiner, R. Scales, K. A. Warren, M. M. Frank, and P. A. Rice \\ National Institute of Allergy and Infectious Diseases, National Institutes of Health, Bethesda, Maryland 20205; and The Maxwell Finland \\ Laboratory for Infectious Diseases, Boston City Hospital, Boston University School of Medicine, Boston, Massachusetts 02118
}

\begin{abstract}
Blocking immunoglobulin G (IgG) inhibits complement-mediated killing of serum-resistant Neisseria gonorrhoeae (GC) in immune human serum. We examined the mechanism of action of blocking IgG. Presensitization of GC with increasing concentrations of blocking IgG or $\mathbf{F}\left(\mathrm{ab}^{\prime}\right)_{2}$ before incubation with bactericidal antibody and absorbed pooled normal human serum increased consumption and deposition of the third component of human complement (C3) and the ninth component of human complement (C9) but inhibited killing in dose-related fashion. We next showed that blocking IgG or $\mathrm{F}\left(\mathrm{ab}^{\prime}\right)_{2}$ partially inhibited binding of bactericidal IgG to GC. Also, binding of a monoclonal antibody recognizing GC outer membrane protein PIII was almost completely inhibited by blocking $F\left(a^{\prime}\right)_{2}$, confirming other work (Rice, P. A., M. R. Tam, and M. S. Blake, manuscript submitted for publication) showing that PIII is a target for blocking antibody. Studies of the $\mathbf{C 3}$ deposition site showed that one quarter of the C3 deposited on GC in the presence of blocking IgG bound covalently to the antibody molecule. Finally, ${ }^{125}$ I-GC constituents with covalently bound $\mathrm{C} 3$ were affinity purified on Sepharose bearing antibodies to $\mathrm{C} 3$ and identified by sodium dodecyl sulfate polyacrylamide gel electrophoresis. $\mathrm{C} 3$ deposition on a 40,000mol wt surface protein was enhanced six- to ninefold by blocking IgG, which indicates that the site of complement deposition was altered by blocking antibody. These studies show that blocking IgG competes with bactericidal antibody for binding to GC, but enhances rather than blocks complement activation, and leads to complement deposition at new sites that do not result in serum killing.
\end{abstract}

\section{Introduction}

Direct complement-mediated killing of gram-negative bacteria may both require and be blocked by antibody within human serum. This enigma is perhaps most clearly apparent for serum killing of Neisseria gonorrhoeae (GC). ${ }^{1}$ Clinical isolates of GC

Address reprint requests to Dr. Joiner, LCI, NIAID, National Institutes of Health, Bldg. 10, Rm. 11N-208, Bethesda, MD 20205.

Received for publication 21 December 1984 and in revised form 10 July 1985.

1. Abbreviations used in this paper: Abs PNHS, absorbed, pooled normal human serum; $\Delta 56$ Abs PNHS, Abs PNHS that has been heated for 30 min at $56^{\circ} \mathrm{C} ; \mathrm{A}: \mathrm{C} 3$ Sepharose, Sepharose $4 \mathrm{~B}$ to which antibodies to human $\mathrm{C} 3$ had been coupled; $\mathrm{C} 3$, third component of human complement; $\mathrm{C}$, ninth component of human complement; DGI, disseminated gonococcal infection; GC, Neisseria gonorrhoeae; $\mathrm{HBSS}^{++}$A, Hank's balanced salt solution containing human serum albumin, $\mathrm{CaCl}_{2}$, and

The Journal of Clinical Investigation, Inc.

Volume 76, November 1985, 1765-1772 require antibody for killing. Natural bactericidal antibody for serum-sensitive isolates of GC is present in normal human serum $(1,2)$, and bactericidal antibody for serum-resistant isolates is often present in convalescent human disseminated gonococcal infection (DGI) serum (3-5). However, the presence of IgGclass blocking antibodies, which are often found in normal human serum, may preclude killing of serum-resistant strains of GC $(6,7)$.

The mechanism of action of the blocking antibody for GC is not known. Unlike blocking antibody for Neisseria meningitidis (8), which is of the $\operatorname{IgA}$ isotype and therefore is unable to activate complement efficiently, the capacity of blocking IgG to interfere with complement activation by $\mathrm{GC}$ has not been tested. It has been speculated that the blocking IgG for GC and for other gram-negative organisms (9-11) may be predominantly those isotypes of $\mathrm{IgG}$ that activate complement poorly. Implicit within this assumption is the idea that blocking antibody competes with or displaces complement-activating bactericidal antibody from the bacterial surface. Neither the capacity of blocking antibody to activate complement nor its capacity to displace or compete for binding with bactericidal antibody have been tested.

We report here studies of these issues. Our results indicate that blocking IgG enhances rather than inhibits complement consumption and deposition on GC, leading to complement deposition at new sites on the outer membrane. Furthermore, blocking $\mathrm{IgG}$ and blocking $\mathrm{F}\left(\mathrm{ab}^{\prime}\right)_{2}$ inhibit binding of bactericidal antibody to GC.

\section{Methods}

Strains. A single serum-resistant strain (WG) of GC was used for all experiments. This strain was isolated from the joint of a patient with DGI, and has been used previously (7). The strain has a protein I (PI) molecular weight of 36,200 and is in the IB3-serovar group (kindly serotyped by Dr. Joan Knapp, University of Washington, Seattle, WA) (12). The organism was grown for $20 \mathrm{~h}$ in candle extinction jars at $37^{\circ} \mathrm{C}$ on a solid GC agar-base medium (Difco Laboratories, Inc., Detroit, MI) containing 1\% Isovitalex. Transparent, nonpiliated colonies were selected as described by Swanson (13). Bacteria were scraped from plates with a sterile inoculating loop and suspended to the desired optical density at room temperature (RT) in Hanks' balanced salt solution containing 1 $\mathrm{mg} / \mathrm{ml}$ human serum albumin (HSA), $0.15 \mathrm{mM} \mathrm{CaCl}_{2}$, and $1.0 \mathrm{mM}$ $\mathrm{MgCl}_{2}\left(\mathrm{HBSS}^{++} \mathrm{A}\right)$.

Serum. Convalescent serum from the DGI patient, obtained $22 \mathrm{~d}$ after infection with the WG strain, was used as the source of bactericidal antibody. Bactericidal antibody in this serum is of the IgG isotype and is directed against lipopolysaccharide. Serum obtained from DGI patients in convalescence may express bactericidal activity against strains resistant

$\mathrm{MgCl}_{2} ; \mathrm{HSA}$, human serum albumin; Mab, monoclonal antibodies; Mab 1D3 and Mab 2E6, Mab directed against gonococcal protein I and protein III, respectively; NPGB, nitrophenyl guanidino benzoate; PAGE, polyacrylamide gel electrophoresis; PI, PII, and PIII, proteins I, II, and III, respectively; $\mathrm{RT}$, room temperature; WG, a single serum-resistant strain of GC. 
to killing by normal human serum $(5,14)$. With the use of a previously reported assay (7), blocking antibody was identified in serum from a normal volunteer. Both convalescent serum and blocking serum were incubated at $56^{\circ} \mathrm{C}$ for $30 \mathrm{~min}$ before being used to inactivate complement.

A pool of normal human serum was used as a source of complement activity. Before use, the serum was absorbed at $0^{\circ} \mathrm{C}$ with glutaraldehydefixed strain WG to remove specific antibody, as previously described (15); aliquots of the serum were then frozen at $-70^{\circ} \mathrm{C}$ (absorbed, pooled normal human serum [Abs PNHS]). Serum absorbed in this way lost $<15 \%$ of starting hemolytic third component of human complement (C3) activity, as assessed in a standard functional C3 titration (16). Serum from a patient with acquired hypogammaglobulinemia was used for some experiments (IgG $<20 \mathrm{mg} / \mathrm{dl}$; IgM $<5 \mathrm{mg} / \mathrm{dl}$; and IgA $<4 \mathrm{mg} / \mathrm{dl}$ ).

Antibody preparation. As previously described (15), IgG was purified from convalescent serum and from blocking serum by both octanoic acid precipitation and batch absorption on Whatman DE52 in $0.05 \mathrm{M}$ acetate buffer, pH 5.2. The resulting IgG was $>95 \%$ pure, as assessed by densitometric scans of samples analyzed by sodium dodecyl sulfate polyacrylamide gel electrophoresis (SDS-PAGE). IgG gave a single precipitin line when tested by double diffusion analysis with antiserum to whole human serum (Miles Laboratories, Elkhart, IN). Bactericidal IgG was iodinated with Iodobeads (Pierce Chemical Co., Rockford, IL) and ${ }^{125}$ I$\mathrm{Na}$ (New England Nuclear, Boston, MA) to a specific activity of $1.12 \times 10^{6} \mathrm{cpm} / \mu \mathrm{g}$ for use in some experiments. To remove aggregates, we centrifuged aliquots of labeled and unlabeled IgG in an air-driven ultracentrifuge (Beckman Instruments, Inc., Spinco Div., Palo Alto, CA) for $15 \mathrm{~min}$ at $178,000 \mathrm{~g}$ before use. $\mathrm{F}\left(\mathrm{ab}^{\prime}\right)_{2}$ fragments of blocking IgG were prepared exactly as described (17), except that the $F\left(a b^{\prime}\right)_{2}$ preparation was also absorbed with protein A-Sepharose by incubation of $F\left(a b^{\prime}\right)_{2}$ at $2.0 \mathrm{mg} / \mathrm{ml}$ in phosphate-buffered saline (PBS) with $0.2 \mathrm{ml}$ of packed protein A-Sepharose (Pharmacia Fine Chemicals, Piscataway, NJ) per milliliter for $60 \mathrm{~min}$ at $\mathrm{RT}$. $\mathrm{F}\left(\mathrm{ab}^{\prime}\right)_{2}$ fragments showed no residual $\mathrm{IgG}$ when analyzed by SDS-PAGE and did not produce a precipitin line when tested in a double diffusion assay with antiserum to the Fc portion of IgG (Cappel Laboratories, Cochranville, PA).

Monoclonal antibodies (Mab) directed against gonococcal PI (Mab 1D3) and protein III (PIII) (Mab 2E6) were prepared and characterized as described previously by Tam et al. (18) and Swanson et al. (19). Mab 1D3 recognizes PI molecules in the 1A-serovar group but not the 1Bserovar group and therefore does not bind to PI on strain WG; this assessment was made through a negative coagglutination assay (16), negative ${ }^{125}$ I-protein A uptake (20), on 1D3-presensitized WG, and negative immunoblot (17) of WG outer membrane with Mab 1D3 (Joiner, K. A., unpublished observations). Mab 2E6 recognizes PIII on a wide variety of $\mathrm{GC}$ strains, including strain WG, as determined by positive coagglutination, ${ }^{125} \mathrm{I}$-protein $\mathrm{A}$ binding, and immunoblot assays (Joiner, K. A., unpublished observations; and Rice, P. A., M. R. Tam, and M. S. Blake, manuscript submitted for publication). Mab were used in ascites fluid for all experiments.

$C 3$ and $C 9$ purification. Human $\mathrm{C} 3$ and ninth component of human complement (C9) were purified from plasma using modifications of the procedure of Hammer et al. (21), as described previously (15). When analyzed by SDS-PAGE under nonreducing conditions, both preparations produced a single band. Purified C3 and C9 were iodinated with ${ }^{125} \mathrm{I}-\mathrm{Na}$ and Iodobeads to a specific activity of 3.89 and $7.71 \times 10^{5} \mathrm{cpm} / \mu \mathrm{g}$, respectively. The specific hemolytic activity of $\mathrm{C} 3$ was $189 \mathrm{U} / \mu \mathrm{g}$ (serum, $184,000 \mathrm{U} / \mathrm{ml}$ ), and that of $C 9$ was $851 \mathrm{U} / \mu \mathrm{g}$ (serum, 40,000 U/ml). Radiolabeled preparations lost $<15 \%$ of initial hemolytic activity. To remove aggregates, we centrifuged both ${ }^{125} \mathrm{I}-\mathrm{C} 3$ and ${ }^{125} \mathrm{I}-\mathrm{C} 9$ for $15 \mathrm{~min}$ at $178,000 \mathrm{~g}$ at RT in an air-driven ultracentrifuge before using them in experiments. The top two-thirds of the sample was aspirated and saved, and the bottom third was discarded.

Iodination of protein A. Protein A (Sigma Chemical Co., St. Louis, MO) was radiolabeled with ${ }^{125} \mathrm{I}-\mathrm{Na}$ with the use of chloramine $\mathrm{T}$ to a specific activity of $6.1 \times 10^{6} \mathrm{cpm} / \mu \mathrm{g}$. ${ }^{125} \mathrm{I}$-Protein A was stored at $4^{\circ} \mathrm{C}$ in PBS containing $0.02 \%$ sodium azide and was centrifuged at 178,000 $\boldsymbol{g}$ for $\mathbf{2 0} \mathrm{min}$ at RT in an air-driven ultracentrifuge before use in experiments.
C3 hemolytic assays. Hemolytic assays for $\mathrm{C} 3$ in serum were performed exactly as reported $(15,16)$.

Serum bactericidal and blocking assays. Serum bactericidal and blocking assays were performed using modifications of previously described methods (7). Bactericidal assays were done by presensitizing 120 $\mu$ l of WG in $\mathrm{HBSS}^{++} \mathrm{A}$ at $\mathrm{OD}_{600}=0.15$ with $20-\mu$ ld dilutions of the indicated antibody source in $\mathrm{HBSS}^{++} \mathrm{A}$ for $20 \mathrm{~min}$ at RT. Then, $60 \mu \mathrm{l}$ of Abs PNHS was added to achieve a final concentration of $30 \%$ Abs PNHS, and incubation was continued for $60 \mathrm{~min}$ at $37^{\circ} \mathrm{C}$. Viable bacterial colonies were enumerated by making serial dilutions of reaction mixtures in $\mathrm{HBSS}^{++} \mathrm{A}$ and plating $50 \mu \mathrm{l}$ of each dilution in duplicate on chocolate agar plates (BBL Microbiology Systems, Cockeysville, MD). Colonies were counted after growth for $30 \mathrm{~h}$ at $37^{\circ} \mathrm{C}$ in candle-extinction jars. Killing was expressed as the percentage or $\log _{10}$ decrease in colony counts compared to presensitized isolates incubated concomitantly in Abs PNHS, which had previously been heated for $30 \mathrm{~min}$ at $56^{\circ} \mathrm{C}$ ( $\triangle 56$ Abs PNHS) to block complement activation.

Blocking assays were performed by incubating WG in $\mathrm{HBSS}^{++} \mathrm{A}$ at $\mathrm{OD}_{600}=0.15$ with $20-\mu \mathrm{l}$ dilutions of the blocking antibody source in $\mathrm{HBSS}^{++} \mathrm{A}$ for $15 \mathrm{~min}$ at RT. Bactericidal antibody was added in $20-\mu \mathrm{l}$ aliquots together with $60 \mu \mathrm{l}$ of Abs PNHS (final 30\% concentration), and incubation was continued for an additional $60 \mathrm{~min}$ at $37^{\circ} \mathrm{C}$. Viable bacterial colonies were measured, and killing was calculated as described above using $\triangle 56$ Abs PNHS for control.

Binding of $C 3$ and $C 9$. Binding of ${ }^{125} \mathrm{I}-\mathrm{C} 3$ and ${ }^{125} \mathrm{I}-\mathrm{C} 9$ to WG during incubation in Abs PNHS was determined exactly as described earlier (15).

Competition binding studies. We tested the ability of $\mathrm{F}\left(\mathrm{ab}^{\prime}\right)_{2}$ blocking antibody to inhibit binding to WG of either IgG in convalescent serum or the protein III (PIII) Mab 2E6. The assay was based on the capacity of immune IgG and of 2E6 attached to WG to bind ${ }^{125} \mathrm{I}$-protein $\mathrm{A}$ as compared with inefficient ${ }^{125} \mathrm{I}$-protein $\mathrm{A}$ binding by $\mathrm{F}\left(\mathrm{ab}^{\prime}\right)_{2}$, blocking antibody attached to WG. WG was suspended in $\mathrm{HBSS}^{++} \mathrm{A}$ to $\mathrm{OD}_{600}$ $=0.15$. To each $600-\mu$ l aliquot, $25 \mu \mathrm{l}$ of dilutions of $\mathrm{F}\left(\mathrm{ab}^{\prime}\right)_{2}$-blocking antibody in $\mathrm{HBSS}^{++} \mathrm{A}$ were added, and the mixtures were incubated at RT for 15 min with periodic agitation. Then, $25 \mu$ of either $\mathrm{HBSS}^{++} \mathrm{A}$ alone, dilutions of convalescent serum, or Mab 2E6 in $\mathrm{HBSS}^{++}$were added to all tubes, and incubation was continued for an additional 20 min at RT. Organisms were washed at RT and suspended to $500 \mu \mathrm{l}$ in $\mathrm{HBSS}^{++} \mathrm{A}$. ${ }^{125} \mathrm{I}$-Protein A in excess was added $\left(5 \mu \mathrm{g} /\right.$ tube; $1.1 \times 10^{6} \mathrm{cpm} /$ $\mu \mathrm{g})$, and a final 30-min incubation at RT was performed. Triplicate samples of $150 \mu \mathrm{l}$ were passed through $0.22-\mu \mathrm{m}$ membranes (Durapore; Millipore Corp., Bedford, MA) with the use of a multiple-sample apparatus (Multivac; Millipore Corp.). Membranes were precoated with 0.5\% HSA in $\mathrm{HBSS}^{++}$before sample application and were washed three times with $1-\mathrm{ml}$ washes of $\mathrm{HBSS}^{++} \mathrm{A}$ after sample application. We determined the amount of ${ }^{125}$ I-protein A retained on the membrane as well as passing through it with a gamma scintillation counter, and calculated the number of applied counts retained on the membrane for all samples. The molecules of "bactericidal IgG-specific" or "Mab 2E6-specific" protein A bound per organism were determined at each input of $F\left(a b^{\prime}\right)_{2}$ as follows: the number of molecules of ${ }^{125} \mathrm{I}$-protein $\mathrm{A}$ bound in samples without added bactericidal IgG or Mab 2E6 was subtracted from the number of molecules of bound ${ }^{125}$ I-protein $A$ in samples containing bactericidal IgG or Mab 2E6.

The capacity of blocking serum or other antibody sources to inhibit uptake of ${ }^{125} \mathrm{I}$-labeled bactericidal IgG on WG was also tested. WG was suspended in $\mathrm{HBSS}^{++} \mathrm{A}$ to $\mathrm{OD}=0.15$, then diluted 1:4 with the same buffer. To each $600-\mu \mathrm{l}$ aliquot was added $25 \mu$ l of either undiluted blocking serum, Mab 2E6, Mab ID3, $\Delta 56$ Abs PNHS, $\Delta 56$ hypogammaglobulinemic serum, convalescent serum, or $25 \mu \mathrm{l}$ of a 1:10 dilution of these samples. Samples were incubated for $20 \mathrm{~min}$ at $\mathrm{RT}$ with periodic agitation. ${ }^{125} \mathrm{I}$-Bactericidal $\mathrm{IgG}$ was added ( $25 \mu \mathrm{l}$ containing $10 \mu \mathrm{g}$ of $\left.{ }^{125} \mathrm{I}-\mathrm{IgG}\right)$, and rotation was continued for an additional $30 \mathrm{~min}$ at $\mathrm{RT}$. Triplicate samples of $200 \mu \mathrm{l}$ were passed through $0.22-\mu \mathrm{m}$ membranes exactly as described above. The percentage of applied counts retained on the membrane was calculated for all samples. The percentage of applied ${ }^{125} \mathrm{I}-\mathrm{IgG}$ retained on the membrane in the sample containing $25 \mu$ l of undiluted $\Delta 56$ con- 
valescent serum was taken as the percentage of nonspecific binding of ${ }^{125} \mathrm{I}-\mathrm{IgG}$ and was subtracted from all other values for calculation of results. Determination of $\mathrm{C} 3$ binding to biotinylated blocking IgG during serum incubation. The binding of $\mathrm{C} 3$ to biotinylated blocking $\mathrm{IgG}$ on GC during serum incubation was measured using minor modifications of recently reported methods $(22,23)$. Briefly, purified blocking IgG was biotinylated with $n$-hydroxysuccinimide biotin (Calbiochem-Behring Corp., La Jolla, CA), then used at a final concentration of $800 \mu \mathrm{g} / \mathrm{ml}$ to presensitize GC in $\mathrm{HBSS}^{++} \mathrm{A}$. Presensitized organisms were then incubated for $45 \mathrm{~min}$ at $37^{\circ} \mathrm{C}$ in $20 \%$ Abs PNHS containing ${ }^{125} \mathrm{I}-\mathrm{C} 3$, with or without added bactericidal antibody, or in $20 \% \triangle 56 \mathrm{Abs}$ PNHS containing ${ }^{125} \mathrm{I}-\mathrm{C} 3$. Additionally, GC not presensitized with biotinyl blocking IgG were incubated concomitantly in $20 \%$ Abs PNHS that contained ${ }^{125} \mathrm{I}$ C3. After incubation, bacterial pellets were washed twice in $\mathrm{HBSS}^{++}$that contained $1 \mathrm{mg} / \mathrm{ml}$ of HSA and $25 \mu \mathrm{M}$ nitrophenyl guanidino benzoate (NPGB); then the pellets were solubilized in $100 \mu \mathrm{l}$ of $1 \%$ SDS at $100^{\circ} \mathrm{C}$ for $5 \mathrm{~min}$. Insoluble material was removed by centrifugation for $2 \mathrm{~min}$ at $12,500 \mathrm{~g}$. The supernatants were diluted with $2 \mathrm{vol}$ of $0.1 \mathrm{M}$ Tris buffer (pH 8.5) containing $0.25 \mathrm{M} \mathrm{NaCl}, 0.3 \%$ SDS, $1 \%$ Triton X-100, and $25 \mu \mathrm{M}$ NPGB (buffer A) and applied to $100 \mu$ l of packed avidin agarose (Sigma Chemical Co.). The mixtures were rotated overnight at RT and washed five times in buffer $\mathrm{A}$, and ${ }^{125} \mathrm{I}-\mathrm{C} 3$ bound to the resin was determined by counting in a gamma scintillation counter.

Determination of $C 3$ acceptor on $G C$. The site of $\mathrm{C} 3$ deposition on GC was determined in the presence and absence of blocking antibody, with the use of modifications of previously described procedures (24, 25 ). The method is based on affinity-purification of surface-iodinated GC constituents that bear covalently attached $\mathrm{C} 3$ after being incubated in serum. These constituents are then identified by SDS-PAGE. Bacteria were surface-iodinated with ${ }^{125} \mathrm{I}-\mathrm{Na}$ (New England Nuclear) as previously described (15). ${ }^{125} \mathrm{I}-\mathrm{GC}$ were suspended in $\mathrm{HBSS}^{++} \mathrm{A}$ so that a 1:10 dilution gave ${ } D_{660}=0.15$, then $250-\mu \mathrm{l}$ aliquots were incubated for $30 \mathrm{~min}$ at RT with $50 \mu \mathrm{l}$ of either blocking serum or buffer. In one experiment, organisms were presensitized with $10 \mu \mathrm{l}$ of bactericidal antibody. The bacteria were pelleted by centrifugation, and the pellets were resuspended in $250 \mu \mathrm{l}$ of $\mathrm{HBSS}^{++} \mathrm{A}$. These suspensions were mixed with an equal volume of either $20 \%$ Abs PNHS or $20 \% \triangle 56 \mathrm{Abs}$ PNHS, and incubation was continued for $40 \mathrm{~min}$ at $37^{\circ} \mathrm{C}$. The organisms were washed twice, and the washed pellets were solubilized in $100 \mu \mathrm{l}$ of $1 \%$ SDS for $5 \mathrm{~min}$ at $100^{\circ} \mathrm{C}$. The detergent-insoluble residue (containing $<10 \%$ of ${ }^{125} \mathrm{I} \mathrm{cpm}$ ) was removed by centrifugation for $2 \mathrm{~min}$ at $12,500 \mathrm{~g}$, and the solubilized supernatant was diluted to $2.5 \mathrm{ml}$ (final SDS concentration $=0.04 \%$ ) with $0.05 \mathrm{M}$ Tris, $100 \mathrm{mM} \mathrm{NaCl}$ buffer ( $\mathrm{pH} 8.0$ ) containing $2 \%$ Nonidet P- $40,0.5 \%$ sodium deoxycholate, $10 \mathrm{mg} / \mathrm{ml}$ of HSA, $25 \mu \mathrm{m}$ NPGB, and $0.02 \% \mathrm{NaN}_{3}$ (buffer B). The mixture was precleared by rotation for $1 \mathrm{~h}$ at RT with $250 \mu \mathrm{l}$ of Sepharose $4 \mathrm{~B}$ (5-7\% of ${ }^{125} \mathrm{I} \mathrm{cpm}$ removed), then the supernatant was applied to $125 \mu \mathrm{l}$ of Sepharose $4 \mathrm{~B}$ to which antibodies to human $\mathrm{C} 3$ had been coupled (A:C3 Sepharose). The mixture was rotated for $3 \mathrm{~h}$ at $\mathrm{RT}$; the resin was then washed four times with buffer $B$, and the counts per minute of the ${ }^{125}$ I that remained bound to the A:C3 Sepharose were determined. At this point, the A:C3 Sepharose bore $\mathrm{C} 3$ with covalently attached ${ }^{125} \mathrm{I}-\mathrm{GC}$ constituents. To release bound ${ }^{125} \mathrm{I}-\mathrm{GC}$ from A:C3 Sepharose and to cleave ester linkages between $\mathrm{C} 3$ and GC acceptor molecules, we incubated the A:C3 Sepharose for 30 min at $37^{\circ} \mathrm{C}$ in $2 \mathrm{ml}$ of buffer B (without HSA), pH 10.5, containing 1 $\mathrm{M} \mathrm{NH} \mathrm{N}_{2} \mathrm{OH}$. The A:C3 Sepharose was removed by centrifugation, and the supernatant was dialyzed overnight at $4^{\circ} \mathrm{C}$ vs. methanol to precipitate released proteins. The flocculent precipitate was collected by centrifugation at $12,500 \mathrm{~g}$, solubilized in SDS sample buffer, and analyzed by $10 \%$ SDS-PAGE autoradiography, as previously described (23).

\section{Results}

Consumption of $C 3$ from Abs PNHS by WG. We first wanted to determine whether blocking antibody inhibited complement activation by WG during incubation in serum. WG was presensitized with increasing concentrations of purified blocking IgG, then incubated in 10\% Abs PNHS in the presence or absence of convalescent DGI serum that contained bactericidal antibody (Fig. 1). In both the presence and absence of bactericidal antibody, $\mathrm{C} 3$ consumption from serum increased with the addition of greater amounts of blocking IgG. Compared with C3 consumption in the absence of added antibody, incubation with bactericidal antibody alone caused a minimal increase in $\mathrm{C} 3$ consumption by WG. As expected, no killing occurred in the absence of bactericidal antibody. Killing induced by bactericidal antibody was blocked in a dose-related fashion by blocking IgG, exactly as reported previously (7). In this experiment, the ratio of blocking $\mathrm{IgG}$ to bactericidal $\mathrm{IgG}$ required for $50 \%$ inhibition of $\log _{10}$ killing was $0.60: 1.00$, which is in accord with previously published data (7). This experiment indicates that blocking IgG does not function by inhibiting complement activation, but in fact increases complement activation by WG in Abs PNHS.

Deposition of ${ }^{125} I-C 3$ on WG presensitized with blocking IgG. Consumption of $\mathrm{C} 3$ from serum is not synonymous with deposition of $\mathrm{C} 3$ on the bacterial surface. We therefore measured C3 deposition on WG under conditions similar to those for the study of $\mathrm{C} 3$ consumption, except that $30 \%$ Abs PNHS was used for the binding studies. Approximately $1 \times 10^{5}$ molecules of $\mathrm{C} 3$ bound per organism in the absence of blocking $\mathrm{IgG}$, whether or not bactericidal antibody was added (Fig. 2). There was a doserelated increase in $\mathrm{C} 3$ binding as blocking IgG was added, such that 2.5-fold more $\mathrm{C} 3$ bound to WG in the presence than in the absence of $800 \mu \mathrm{g} / \mathrm{ml}$ of blocking IgG. There was no significant difference between $\mathrm{C} 3$ deposition in either the presence or the absence of bactericidal antibody. Therefore, blocking IgG enhances $\mathrm{C} 3$ deposition on WG in Abs PNHS.

Deposition of ${ }^{125} \mathrm{I}-\mathrm{C} 3$ on $W G$ presensitized with blocking $F\left(a b^{\prime}\right)_{2}$. Rice and Kasper (7) have previously reported that $\mathrm{F}\left(\mathrm{ab}^{\prime}\right)_{2}$ fragments of blocking IgG will inhibit serum killing of GC.

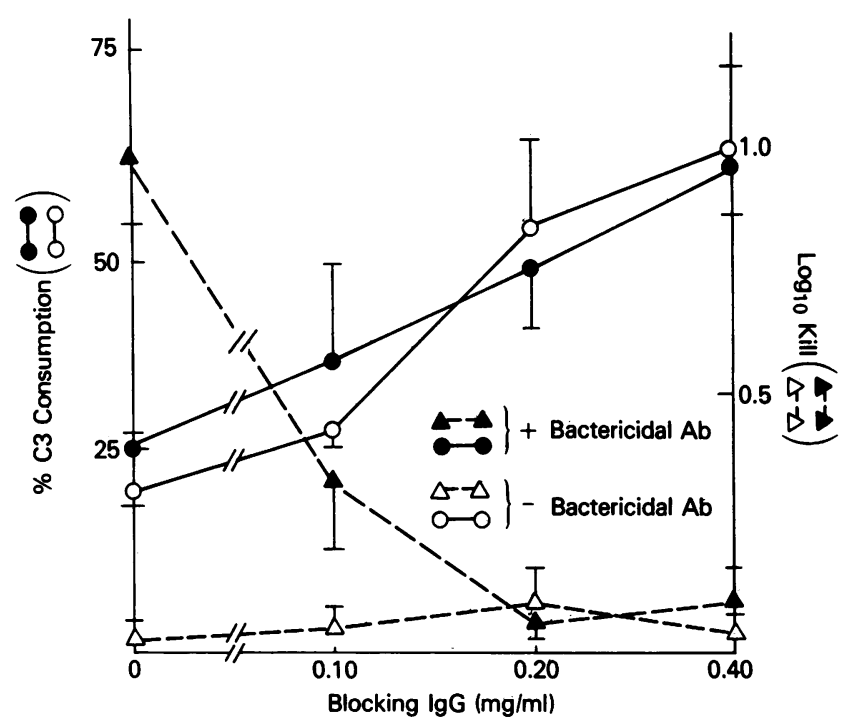

Figure 1. Percent C3 consumption and $\log _{10}$ kill vs. blocking IgG. Strain WG was presensitized with blocking IgG, then incubated in $10 \%$ Abs PNHS with or without added bactericidal antibody. After a 60 -min incubation at $37^{\circ} \mathrm{C}$, hemolytic $\mathrm{C} 3$ titrations were performed, and the extent of bacterial killing was measured. The percentage of $\mathrm{C} 3$ consumption was determined compared with a sample of $10 \%$ Abs PNHS incubated concomitantly without added WG. Results shown are the mean $\pm \mathrm{SD}$ for two experiments. 


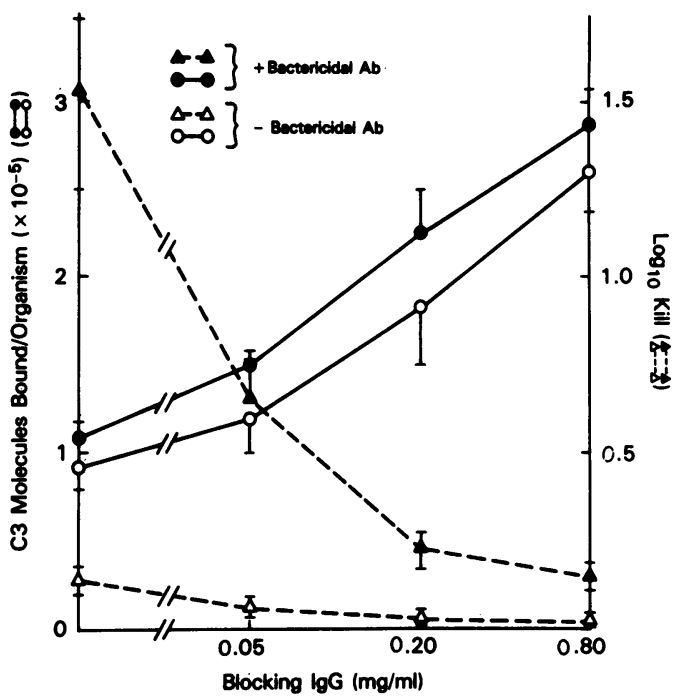

Figure 2. $\mathrm{C} 3$ binding and $\log _{10}$ kill vs. blocking IgG. Binding of $\mathrm{C} 3$ and killing of WG were measured after presensitization with IgG blocking antibody, followed by incubation in Abs PNHS containing ${ }^{125} \mathrm{I}-\mathrm{C} 3$. Results were compared in the presence and absence of added bactericidal antibody. Each point represents the mean \pm SD for two experiments. $\mathrm{C} 3$ binding at blocking IgG inputs of 0.20 and $0.80 \mathrm{mg} / \mathrm{ml}$ was significantly greater than in the absence of added antibody.

Therefore, we measured $\mathrm{C} 3$ binding on WG after presensitization with increasing amounts of blocking $\mathrm{F}\left(\mathrm{ab}^{\prime}\right)_{2}$ and incubation in $30 \%$ Abs PNHS containing bactericidal antibody. There was a dose-related inhibition of killing and an overall increase in C3 binding on WG as the concentration of blocking $\mathrm{F}\left(\mathrm{ab}^{\prime}\right)_{2}$ was increased to $960, \mu \mathrm{g} / \mathrm{ml}$ (Fig. 3). Concentrations of blocking $\mathrm{F}\left(\mathrm{ab}^{\prime}\right)_{2}$ that were higher than of blocking IgG were required to increase $\mathrm{C} 3$ binding significantly in comparison to $\mathrm{C} 3$ binding on organisms not incubated with antibody. At low concentrations of blocking $\mathrm{F}\left(\mathrm{ab}^{\prime}\right)_{2}(<120 \mu \mathrm{g} / \mathrm{ml})$ that were still capable of blocking killing, no increase in $\mathrm{C} 3$ deposition was noted, suggesting

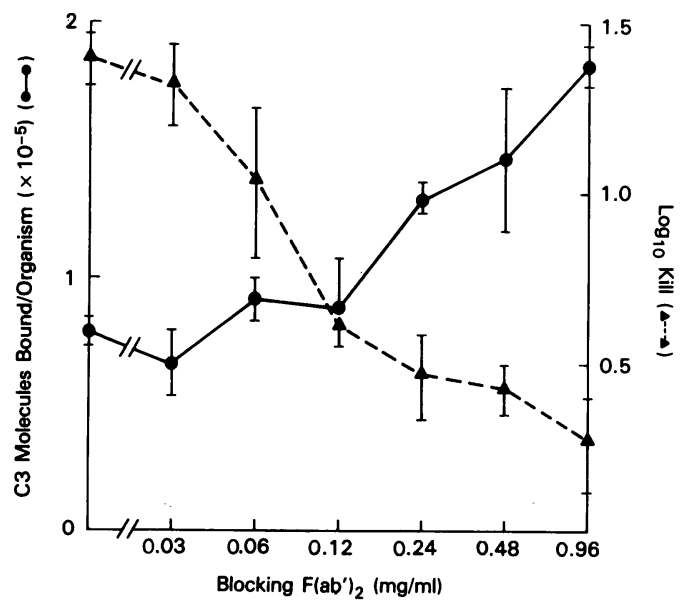

Figure 3. $\mathrm{C} 3$ binding and $\log _{10}$ kill vs. blocking $\mathrm{F}\left(\mathrm{ab}^{\prime}\right)_{2}$. Binding of $\mathrm{C} 3$ and killing of WG were measured after presensitization with $F\left(a b^{\prime}\right)_{2}$ blocking antibody followed by incubation in Abs PNHS containing ${ }^{125} \mathrm{I}-\mathrm{C} 3$ and added bactericidal antibody. Results shown are the mean \pm SD for two experiments. C3 binding was significantly higher at blocking $\mathrm{F}\left(\mathrm{ab}^{\prime}\right)_{2}$ inputs of $0.24 \mathrm{mg} / \mathrm{ml}$ or greater when compared with organisms not presensitized with blocking $\mathrm{F}\left(\mathrm{ab}^{\prime}\right)_{2}$. that complement deposition mediated by blocking antibody is not necessary for the observed inhibition of killing.

Binding of C9 to $W G$ presensitized with blocking IgG. A dissociation between binding of $\mathrm{C} 3$ and binding of the bactericidal C5b-9 complex to the bacterial surface has been reported previously for serum-resistant strains of Salmonella and Escherichia coli (26). To address this issue for WG, we measured deposition of C9 on WG during incubation in 30\% Abs PNHS with added bactericidal antibody (Table I). C9 binding on WG increased significantly after presensitization with 400 or 1,600 $\mu \mathrm{g} / \mathrm{ml}$ of blocking IgG, and killing was blocked substantially at both inputs of blocking IgG. This experiment indicates that blocking IgG enhances deposition of the terminal complement complex C5b-9 on WG and shows that blocking IgG does not function by selective inhibition of either the $\mathrm{C} 5$ convertase or a later step in C5b-9 formation; rather, blocking IgG leads to deposition of C5b-9, which is in a nonbactericidal configuration.

Competition binding studies with blocking and bactericidal antibody. We next investigated whether presensitization of WG with blocking antibody could interfere with subsequent binding of bactericidal antibody. Two approaches were used, as described in Methods. First, uptake of ${ }^{125}$ I-protein A was determined on WG that was presensitized first with increasing concentrations of purified $F\left(a b^{\prime}\right)_{2}$ blocking antibody, then with a fixed amount of convalescent DGI serum that contained bactericidal IgG. $\mathrm{F}\left(\mathrm{ab}^{\prime}\right)_{2}$ fragments will not bind ${ }^{125}$ I-protein $\mathrm{A}$ with high affinity, whereas intact IgG binds ${ }^{125}$ I-protein A avidly. A dose-related inhibition of ${ }^{125}$ I-protein $A$ binding is observed as the concentration of $\mathrm{F}\left(\mathrm{ab}^{\prime}\right)_{2}$ blocking antibody is increased (Fig. 4), which suggests that $\mathrm{F}\left(\mathrm{ab}^{\prime}\right)_{2}$ blocking antibody inhibits binding of IgG within convalescent serum to WG. It was not possible to raise the concentration of $\mathrm{F}\left(\mathrm{ab}^{\prime}\right)_{2}$ blocking antibody to $>16 \mu \mathrm{g} / \mathrm{ml}$, since at higher $\mathrm{F}\left(\mathrm{ab}^{\prime}\right)_{2}$ concentrations, ${ }^{125} \mathrm{I}$-protein $\mathrm{A}$ binding increased on strains not subsequently incubated with bactericidal antibody. It is likely that this represents the interaction of ${ }^{125} \mathrm{I}$ protein $A$ with $F\left(a^{\prime}\right)_{2}(27)$ rather than with contaminating IgG, since the $F\left(a b^{\prime}\right)_{2}$ preparation showed no intact IgG by SDS-PAGE and did not react with anti- $\mathrm{Fc}$ fragment antiserum by double diffusion. Furthermore, it has recently been demonstrated (32) that blocking IgG in the same serum source used in these studies is almost exclusively $\mathrm{IgG} 3$, an isotype with poor protein A reactivity via the $\mathrm{Fc}$ region (28).

Next, the capacity of blocking serum and other antibody sources to inhibit binding of ${ }^{125}$ I-bactericidal IgG to WG was

Table I. C9 Binding and $\log _{10}$ Kill on WG Presensitized with Blocking IgG

\begin{tabular}{lll}
\hline Blocking IgG & Molecules C9/organism & Log $_{10}$ kill \\
\hline$m g / m l$ & $\times 10^{-4}$ & \\
0.00 & $4.62 \pm 1.15^{*}$ & $1.52 \pm 0.27^{*}$ \\
0.40 & $6.27 \pm 0.96$ & $0.19 \pm 0.09$ \\
1.60 & $7.63 \pm 0.74 \ddagger$ & $0.14 \pm 0.01$
\end{tabular}

Strain WG in $\mathrm{HBSS}^{++} \mathrm{A}$ at $\mathrm{OD}_{600}=0.15$ was presensitized with dilutions of purified blocking IgG or buffer for 15 in at RT, then incubated for $60 \mathrm{~min}$ in $30 \%$ Abs PNHS containing ${ }^{125} \mathrm{I}-\mathrm{C} 9$ and bactericidal IgG. The total number of $\mathrm{C} 9$ molecules bound per organism and $\log _{10}$ kill were determined as described in Methods.

* Mean \pm SD for three experiments.

$\ddagger P<0.05$ in comparison to 0.00 blocking IgG. 


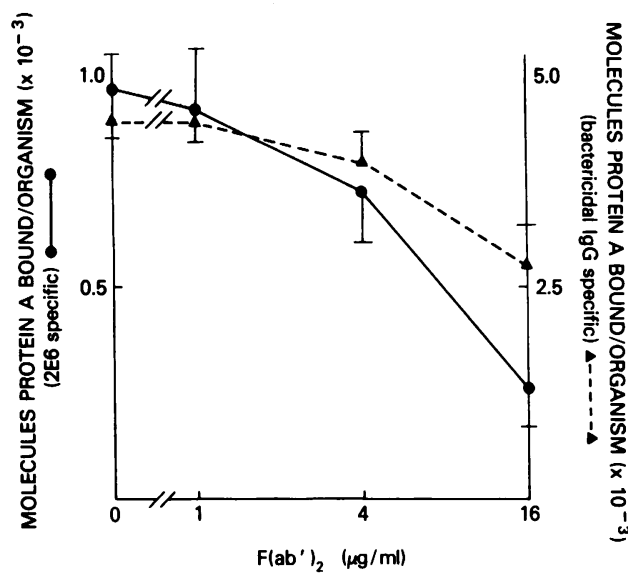

Figure 4. Blocking $\mathrm{F}\left(\mathrm{ab}^{\prime}\right)_{2}$ inhibits binding of bactericidal IgG and Mab 2E6. WG was sensitized with increasing amounts of blocking $\mathrm{F}\left(\mathrm{ab}^{\prime}\right)_{2}$, then incubated with bactericidal antibody or Mab 2E6. The organisms were washed, ${ }^{125}$ I-protein A was added, and the molecules of protein $A$ bound were determined. The assay was based on the fact that $\mathrm{F}\left(\mathrm{ab}^{\prime}\right)_{2}$ fragments will not bind ${ }^{125}$ I-protein A with high affinity, whereas bactericidal IgG and Mab $2 \mathrm{E} 6$ bind ${ }^{125} \mathrm{I}$-protein $\mathrm{A}$ avidly. Results represent the mean \pm SD for three experiments.

measured (Fig. 5). Both blocking serum and Mab 2E6 significantly inhibited binding of ${ }^{125} \mathrm{I}$-bactericidal IgG to WG, in comparison to serum sources $(\Delta 56$ Abs PNHS and $\Delta 56$ hypogammaglobulinemic serum) or Mab 1D3, which do not contain specific antibodies for strain WG. The better inhibition with a 1:10 dilution of Mab 2E6 than with undiluted 2E6 was not explored further, except to demonstrate that for all antibody sources tested, inhibition at 1:50 and 1:100 dilutions was lower than at a 1:10 dilution. Therefore, by two separate techniques,

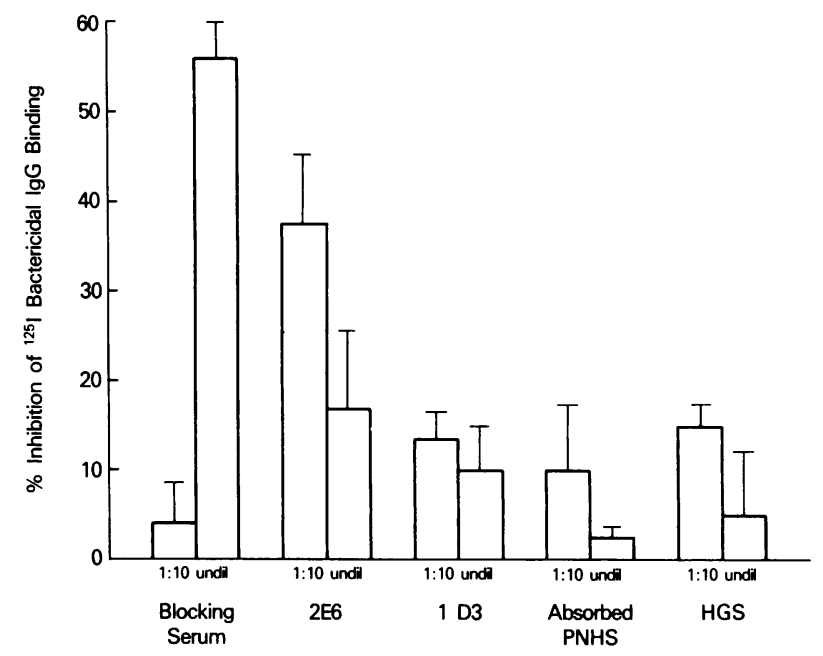

Figure 5. Blocking serum and Mab 2E6 inhibit binding of ${ }^{125}$ I bactericidal IgG. Strain WG was sensitized with either blocking serum, Mab 2E6, Mab ID3 (which does not bind to WG), or with two sources of serum ( $\Delta 56 \mathrm{Abs}$ PNHS and $\Delta 56$ hypogammaglobulinemic serum) that do not contain specific antibodies for WG. Binding of ${ }^{125}$ I-bactericidal IgG was then measured. Nonspecific binding of ${ }^{125}$ I-bactericidal IgG was determined by measuring uptake in the presence of a 250 fold excess of unlabeled bactericidal IgG. Results are expressed as the percent inhibition of specific ${ }^{125}$ I-bactericidal $\mathrm{IgG}$ uptake compared to binding on WG sensitized in buffer alone. Results shown are the mean \pm SD for three experiments. we have shown that blocking antibody inhibits binding of IgG within convalescent serum to WG.

The capacity of $F\left(a b^{\prime}\right)_{2}$ blocking antibody to inhibit the binding of the PIII Mab 2E6 to WG was also tested. As shown in Fig. 4, nearly $75 \%$ inhibition of 2E6 binding occurred at a concentration of $\mathrm{F}\left(\mathrm{ab}^{\prime}\right)_{2}$ blocking antibody of only $16 \mu \mathrm{g} / \mathrm{ml}$. This efficient inhibition suggests that $F\left(a b^{\prime}\right)_{2}$ blocking antibody is directed, at least in part, against PIII.

Determination of $C 3$ binding to biotinylated blocking IgG during serum incubation. We have recently shown that immune IgG bearing covalently bound $\mathrm{C} 3 \mathrm{~b}$ has enhanced bactericidal activity for $E$. coli 0111 and we have suggested that formation of C3b-IgG complexes may be critical for effective bacterial killing by complement (23). We therefore considered the possibility that the blocking IgG for GC did not serve as an acceptor for C3 deposition during complement activation. GC presensitized with biotinylated blocking IgG were incubated in serum that contained ${ }^{125} \mathrm{I}-\mathrm{C} 3$, and the percentage of $\mathrm{C} 3$ covalently attached to biotinyl $\mathrm{IgG}$ was determined by affinity purification of the SDS-solubilized organisms on avidin agarose (Table II). Between 18.9 and $24.4 \%$ of $\mathrm{C} 3$ attached to GC was bound to biotinyl blocking IgG, in comparison to $\sim 1 \%$ binding in controls. $\mathrm{C} 3$ binding to blocking IgG was not significantly altered by bactericidal antibody, although we have recently found (not shown) that bactericidal IgG for WG serves as an acceptor for C3 deposition. These results indicate that the blocking IgG on GC serves as an acceptor for $\mathrm{C} 3$ deposition and that antibody molecules that bind $\mathrm{C} 3$ during complement activation are not necessarily bactericidal.

Determination of $C 3$ acceptor site on $G C$. We examined the possibility that the site of $\mathrm{C} 3$ deposition (C3 acceptor) on $\mathrm{GC}$ was different, depending on whether blocking $\mathrm{IgG}$ was present or absent. Surface-iodinated GC were presensitized with blocking IgG or bactericidal antibody, incubated in serum, and the ${ }^{125} I$ gonococcal constituents bearing $\mathrm{C} 3$ were affinity-purified on A:C3 Sepharose (Table III). Significantly more ${ }^{125}$ I-GC bound to A:C3 Sepharose for samples incubated in 20\% Abs PNHS than for the control sample incubated in $20 \% \Delta 56$ Abs PNHS. Interestingly, presensitization with blocking antibody did not increase binding of ${ }^{125} \mathrm{I}-\mathrm{GC}$ to A:C3 Sepharose in comparison with organisms not incubated with antibody, despite leading to more $\mathrm{C} 3$ deposition on the bacterial surface (Fig. 2).

${ }^{125} \mathrm{I}-\mathrm{GC}$ constituents linked to $\mathrm{C} 3$ by an ester bond were released with hydroxylamine ( $>87 \%$ release) and analyzed by 10\% SDS-PAGE (Fig. 6). The only major difference between

Table II. Binding of C3 to Biotinylated Blocking IgG on GC

\begin{tabular}{|c|c|c|}
\hline Antibody & Serum & $\begin{array}{l}\text { Percent of }{ }^{125} \mathrm{I}-\mathrm{C} 3 \\
\text { on } \mathrm{GC} \text { bound to } \\
\text { avidin agarose }\end{array}$ \\
\hline Biotinyl blocking IgG & $\begin{array}{l}20 \% \text { Abs PNHS } \\
+ \text { bactericidal antibody }\end{array}$ & $18.9 \pm 3.6$ \\
\hline Biotinyl blocking IgG & $20 \%$ Abs PNHS & $24.4 \pm 4.7$ \\
\hline Biotinyl blocking IgG & $20 \% \Delta 56$ Abs PNHS & $0.8 \pm 0.4$ \\
\hline None & $20 \%$ Abs PNHS & $1.2 \pm 0.3$ \\
\hline
\end{tabular}

Bacteria were presensitized with the indicated antibody source. Biotinyl blocking antibody was used at a final concentration of $720 \mu \mathrm{g} / \mathrm{ml}$, and the final concentration for bactericidal antibody was $200 \mu \mathrm{g} / \mathrm{ml}$. The cells were incubated in $20 \%$ Abs PNHS containing ${ }^{125} \mathrm{I}-\mathrm{C} 3$, solubilized in $1 \%$ SDS, and applied to avidin agarose; the percentage of ${ }^{125} \mathrm{I}-\mathrm{C} 3$ bound was then determined. Results shown are the mean $\pm S D$ for two experiments. 
Table III. Binding of ${ }^{125}$ I-GC Constituents to A:C3 Sepharose

\begin{tabular}{lll}
\hline Antibody & Serum & $\begin{array}{l}\text { Percent of }{ }^{125} \text { I-GC bound } \\
\text { to A:C3 Sepharose }\end{array}$ \\
\hline None & $20 \%$ Abs PNHS & $6.60 \pm 1.41^{*}$ \\
Bactericidal antibody & $20 \%$ Abs PNHS & $5.27 \pm 0.65 \ddagger$ \\
Blocking IgG & $20 \%$ Abs PNHS & $4.57 \pm 1.00 \ddagger$ \\
Blocking IgG & $20 \% \Delta 56$ Abs PNHS & $2.02 \pm 0.84$ \\
\hline
\end{tabular}

Surface-iodinated GC were presensitized with the indicated antibody source, then incubated in Abs PNHS. The cells were solubilized in 1\% SDS; the sample was then diluted with buffer B to achieve a final SDS concentration of $0.04 \%$ and applied to $\mathrm{A}: \mathrm{C} 3$ Sepharose. The percentage of ${ }^{125} \mathrm{I}-\mathrm{GC}$ bound to A:C3 Sepharose was determined. Results shown are mean \pm SD for two experiments.

* $P<0.02$ compared with organisms incubated in $20 \% \Delta 56$ Abs PNHS.

$\ddagger P<0.05$ compared with organisms incubated in $20 \% \Delta 56$ Abs PNHS.

experimental and control samples, as determined by densitometric scanning, was the presence of a prominant $40,000-\mathrm{mol}$ wt band in the organisms presensitized with blocking IgG (indicated by - in + Blocking IgG lane). This band was six- to ninefold more intense in this sample than in the other experimental lanes and was barely discernible in native ${ }^{125} \mathrm{I}-\mathrm{GC}$. In other experiments (not shown), the 40,000-mol wt band was more clearly present as a discrete but still very minor band in native ${ }^{125} \mathrm{I}-\mathrm{GC}$. This band is not being artifactually increased in density by blocking antibody, since we found (in experiments not shown) that ( $a$ ) addition of blocking $\mathrm{IgG}$ after completion of serum incubation did not enhance the 40,000-mol wt band and $(b)$ blocking IgG did not immunoprecipitate the 40,000mol wt band from ${ }^{125}$ I-GC. Although the experiments shown used GC bearing PII (band at $24,500 \mathrm{~mol} \mathrm{wt}$ ), identical results were obtained with GC that lacked PII. Bactericidal antibody

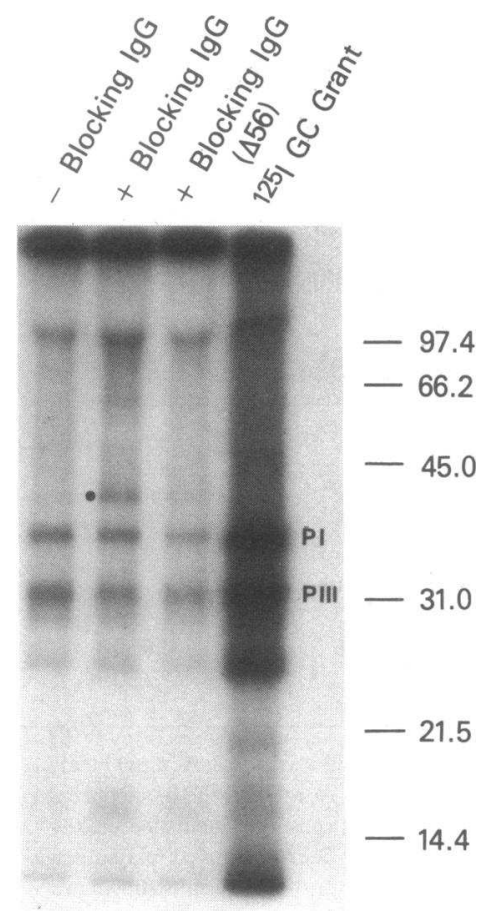

Figure 6. Blocking IgG changes the $\mathrm{C} 3$ acceptor on ${ }^{125}$ I GC grant. GC was surface-iodinated with iodogen (right-hand lane) then presensitized with blocking antibody (+ blocking IgG) or buffer (- blocking IgG), and incubated in $20 \%$ Abs PNHS (left two lanes) or $20 \% \triangle 56$ Abs PNHS $(\Delta 56$ lane). ${ }^{125}$ I-GC constituents bearing $C 3$ were affinity-purified on A:C3 Sepharose, then released with $1 \mathrm{M}$ $\mathrm{NH}_{2} \mathrm{OH}, \mathrm{pH} 10.5$, and analyzed by $10 \%$ SDS-PAGE autoradiography. used at a concentration fivefold lower than the concentration of blocking antibody did not change the C3 acceptor site (not shown). Earlier data indicated that this amount of bactericidal antibody rendered the organism susceptible to complement-mediated killing without significantly increasing either $\mathrm{C} 3$ consumption or deposition (Figs. 1 and 2). These results indicate that blocking antibody changes the $\mathrm{C} 3$ acceptor on GC.

\section{Discussion}

We have shown in this paper that blocking IgG and $F\left(a b^{\prime}\right)_{2}$ enhance complement consumption and deposition on a serumresistant strain of GC, although they inhibit killing of the organism. Complement deposition is increased through $\mathrm{C} 9$, as shown by binding $\mathrm{C} 9$ to the bacterial surface. Blocking IgG and $F\left(a b^{\prime}\right)_{2}$ are in part directed against an antigenically conserved gonococcal outer membrane protein, PIII (19). These blocking antibodies or fragments compete with binding of bactericidal IgG to the strain. These results suggest that the mechanism of action of blocking antibody is to replace binding of bactericidal IgG with an antibody that leads to deposition of nonbactericidal C5b-9.

We have demonstrated previously $(15,20,29)$ that serumresistant GC activate complement and that complement components are deposited on the outer membrane of these organisms without causing killing. Bactericidal rabbit antibody for GC functions by altering the site of deposition or molecular configuration of the C5b-9 that attaches to the bacterial surface (15, 29). Recently, we have also shown that murine Mab directed against identical or closely associated surface-exposed epitopes on gonococcal PI differ markedly in bactericidal activity, despite leading to deposition of nearly equivalent numbers of $\mathrm{C} 9 \mathrm{~mol}-$ ecules per organism (20). The nonbactericidal Mab compete with bactericidal Mab for binding to the gonococcal surface and thus block serum killing without significantly altering the extent of complement deposition. The results presented in this paper extend these observations to polyclonal human antibodies for GC, by showing that not all polyclonal antibodies capable of activating complement on GC lead to deposition of bactericidal C5b-9. Moreover, such antibodies may be found naturally in humans.

Bactericidal antibodies against both serum-sensitive and serum-resistant strains of GC are directed mainly against lipopolysaccharides $(2,5,30,31)$. Normal and convalescent serum may contain antibodies that recognize PI; these antibodies may also be bactericidal (14; authors' unpublished observations). The presence of blocking antibody in normal human serum has been identified in the fraction of antibody recognizing outer membrane protein (7). These antibodies are found in most normal human sera that have been tested (7). Rice et al. (32; also Rice, P. A., M. R. Tam, and M. S. Blake, manuscript submitted for publication) have shown recently that blocking antibody for WG in the serum employed in these studies and other sera tested recognize PIII almost exclusively. Although extensive serologic testing for the presence of PIII antibodies in normal human sera has not been performed, many normal human sera that have been tested contain IgG antibodies against this antigenically conserved surface protein (33; also authors' unpublished data). In addition, the observation that bactericidal antibody development in patients convalescing from DGI is often nonexistent or meager (34), despite high-titered antibody rises measured by indirect immunofluorescence (35), suggests that blocking anti- 
bodies may result from specific antigenic challenge. We have demonstrated in separate experiments (not shown) that selective PIII antibody depletion from DGI convalescent sera (other than WG immune serum) that do not exhibit bactericidal activity (34) restores this activity (Rice, P. A., M. R. Tam, and M. S. Blake, manuscript submitted for publication). These data are concordant with our results, since we found that low concentrations of $\mathrm{F}\left(\mathrm{ab}^{\prime}\right)_{2}$ blocking antibody effectively inhibited binding of the PIII Mab 2E6 to WG. Interestingly, Sarafian et al. (36) demonstrated that normal human serum could inhibit binding of Mab 2E6 to the serum-resistant strain FA171. However, all inhibition of 2E6 binding could be removed by absorption of normal human serum with purified PI, which suggests that steric hinderance played a critical role in these competition binding studies. Previously, we have shown that 2E6 can inhibit binding of a PI Mab, 4G5, to the surface of serum-resistant GC strain R11 (20). Thus, it is neither surprising nor unexpected, given the proximity of PI, PIII, and lipopolysaccharide within the gonococcal outer membrane (37-39), that blocking $F\left(a b^{\prime}\right)_{2}$ directed against PIII may inhibit binding of bactericidal antibody directed against either lipopolysaccharide or PI.

The capacity of serum-resistant strains of GC to activate the alternative pathway in the absence of serum killing has been shown previously (40). $\mathrm{F}\left(\mathrm{ab}^{\prime}\right)_{2}$ fragments of blocking antibody activated and deposited $\mathrm{C} 3$ on WG. $\mathrm{F}\left(\mathrm{ab}^{\prime}\right)_{2}$ fragments cannot activate complement via the classical pathway, but are capable of initiating or facilitating alternative pathway activation in many systems (reviewed in reference 41 ). It is possible, therefore, that blocking antibody mediated alternative pathway activation in the experiments of Densen et al. (40).

Blocking IgG alters the site of C3 deposition on GC, both by serving as an acceptor for $\mathrm{C} 3$ deposition and by redirecting $\mathrm{C} 3$ deposition to different bacterial constituents. The percentage of ${ }^{125} \mathrm{I}-\mathrm{GC}$ constituents that are affinity-purified on A:C3 Sepharose is lower in the presence than in the absence of blocking IgG (Table III); this is due in part to the fact that a substantial fraction of $\mathrm{C} 3$ deposited by blocking IgG is bound to the antibody itself. It is also possible that blocking IgG redirects $\mathrm{C} 3$ to nonlabeled constituents, such as lipopolysaccharide, or that multiple C3 molecules are deposited on individual gonococcal constituents. These experiments do not exclude the possibility that the redistribution of $\mathrm{C} 3$ initiated by blocking IgG may be a passive phenomenon dictated by a masking of certain C3 acceptor sites by the blocking IgG molecule. This possibility is supported by the observation that $\mathrm{C} 3$ deposition is directed to a $40,000-\mathrm{mol}$ wt constituent on GC presensitized with blocking IgG; yet the blocking antibody itself recognizes predominantly PIII (Rice, P. A., M. R. Tam, and M. S. Blake, manuscript submitted for publication) and does not recognize the $40,000-\mathrm{mol}$ wt molecule by immunoprecipitation.

For the studies reported here, the entire IgG fraction of blocking serum was used rather than affinity-purified antibodies directed against specific gonococcal constituents. Therefore, it cannot be assumed that antibodies with different antigen specificities within the blocking IgG preparation will activate complement equivalently. Nonetheless, we suggest that it is either the nature of the antibody itself or the location of the epitope recognized by the antibody, rather than the antigenic specificity of antibody, that determines bactericidal activity. Such a premise is based on the fact that different Mab, all directed at a single protein PI, can vary in bactericidal activity for GC (20) and that the PIII Mab 2E6 is bactericidal for some strains of GC at high concentrations (Joiner, K. A., and J. Swanson, unpublished observations; Rice, P. A., unpublished observations). Blocking IgG, regardless of the antigenic specificity, competes for binding with bactericidal antibody and leads to deposition of nonbactericidal C5b-9.

\section{Acknowledgment}

This work was supported in part by National Institutes of Health grant NIAID 15633.

\section{References}

1. Schoolnik, G. C., H. D. Ochs, and T. M. Buchanan. 1979. Immunoglobulin class responsible for gonococcal bactericidal activity of normal human sera. J. Immunol. 122:1771-1779.

2. Tramont, E. C., J. C. Sadoff, and C. Wilson. 1977. Variability of the lytic susceptibility of Neisseria gonorrhoeae to human sera. J. Immunol. 118:1843-1851.

3. Brooks, G. F., K. S. Israel, and B. H. Peterson. 1976. Bactericidal and opsonic activity against Neisseria gonorrhoeae in sera from patients with disseminated gonococcal infection. J. Infect. Dis. 134:450-461.

4. Rice, P. A., and D. L. Goldenberg. 1981. Clinical manifestations of disseminated infection caused by Neisseria gonorrhoeae are linked to differences in bactericidal reactivity of infecting strains. Ann. Int. Med. 95:175-178.

5. Rice, P. A., and D. L. Kasper. 1977. Characterization of gonococcal antigens responsible for induction of bactericidal antibody in disseminated infection. J. Clin. Invest. 60:1149-1158.

6. McCutchan, J. A., D. Katzenstein, D. Norquist, G. Chikami, A. Wunderlich, and A. I. Braude. 1978. Role of blocking antibody in disseminated gonococcal infection. J. Immunol. 121:1884-1888.

7. Rice, P. A., and D. L. Kasper. 1982. Characterization of serum resistance of Neisseria gonorrhoeae that disseminate. J. Clin. Invest. 70: 157-167.

8. Griffiss, J. M., D. D. Broud, and M. A. Bertram. 1975. Bactericidal activity of meningococcal antisera: blocking by IgA of lytic antibody in human convalescent sera. J. Immunol. 114:1779-1784.

9. Guttman, R. M., and B. A. Waisbren. 1975. Bacterial blocking activity of specific IgG in chronic Pseudomonas aeruginosa infection. Clin. Exp. Immunol. 19:121-130.

10. Taylor, P. W. 1972. An antibactericidal factor in the serum of two patients with infection of the upper respiratory tract. Clin. Sci. (Lond.). 434:23-27.

11. Waisbren, B. A., and I. Brown. 1966. A factor in the serum of patients with persisting infection that inhibits the bactericidal activity of normal serum against the organism that is causing the infection. J. Immunol. 97:431-437.

12. Knapp, J. S., M. R. Tam, R. C. Nowinski, K. K. Holmes, and E. G. Sandström. 1984. Serological classification of Neisseria gonorrhoeae with use of monoclonal antibodies to gonococcal outer membrane protein I. J. Infect. Dis. 150:44-48.

13. Swanson, J. 1978. Studies on gonococcus infection. XII. Colony color and opacity variants of gonococci. Infect. Immun. 19:320-331.

14. Hook, E. W., III, D. A. Olsen, and T. M. Buchanan. 1984. Analysis of the antigen specificity of the human serum immunoglobulin $\mathrm{G}$ immune response to complicated gonococcal infection. Infect. Immun. 43:706709.

15. Joiner, K. A., K. A. Warren, E. J. Brown, J. Swanson, and M. M. Frank. 1983. Studies on the mechanism of bacterial resistance to complement-mediated killing. IV. C5b-9 forms high molecular weight complexes with bacterial outer membrane constituents on serum-resistant but not on serum-sensitive Neisseria gonorrhoeae. J. Immunol. 131:14431451.

16. Gaither, T. A., and M. Frank. 1979. Complement. In Clinical Diagnosis and Management by Laboratory Methods. J. B. Henry, editor. W. B. Saunders Co., Philadelphia. 1245-1264. 
17. Joiner, K. A., R. C. Goldman, C. H. Hammer, L. Leive, and M. M. Frank. 1983. Studies on the mechanism of bacterial resistance to complement-mediated killing. V. IgG and $\mathrm{F}\left(\mathrm{ab}^{\prime}\right)_{2}$ mediate killing of $E$. coli 0111B4 by the alternative complement pathway without increasing C5b-9 deposition. J. Immunol. 131:2563-2569.

18. Tam, M. R., R. M. Buchanan, E. G. Sandström, K. K. Holmes, J. S. Knapp, A. W. Siadak, and R. C. Nowinski. 1982. Serological classification of Neisseria gonorrhoeae with monoclonal antibodies. Infect. Immun. 36:1042-1053.

19. Swanson, J., L. W. Mayer, and M. R. Tam. 1982. Antigenicity of Neisseria gonorrhoeae outer membrane protein III detected by immunoprecipitation and Western blot transfer with a monoclonal antibody. Infect. Immun. 38:668-672.

20. Joiner, K., K. Warren, M. Tam, and M. Frank. 1985. Monoclonal antibodies directed against gonococcal protein I vary in bactericidal activity. J. Immunol. 134:3411-3419.

21. Hammer, C. H., G. H. Wirtz, L. Renfer, H. D. Gresham, and B. F. Tack. 1981. Large scale isolation of functionally active components of the human complement system. J. Biol. Chem. 256:3995-4007.

22. Brown, E. J., M. Berger, K. A. Joiner, and M. M. Frank. 1983. Classical complement pathway activation by antipneumococcal antibodies leads to covalent binding of $\mathrm{C} 3 \mathrm{~b}$ to antibody molecules. Infect. Immun. 42:594-598.

23. Joiner, K. A., L. F. Fries, M. A. Schmetz, and M. M. Frank. 1985. IgG bearing covalently bound $\mathrm{C} 3 \mathrm{~b}$ has enhanced bactericidal activity for Escherichia coli 0111. J. Exp. Med. 162:877-889.

24. Joiner, K. A., R. Goldman, M. Schmetz, M. Berger, C. H. Hammer, M. M. Frank, and L. Leive. 1984. A quantitative analysis of C3 binding to $\mathrm{O}$-antigen capsule, lipopolysaccharide, and outer membrane protein of $E$. coli 0111B4. J. Immunol. 132:369-375.

25. Joiner, K. A., S. Hieny, L. V. Kirchhoff, and A. Sher. 1985. GP72, the 72,000 dalton glycoprotein, is the membrane acceptor for C3 on Trypanosoma cruzi epimastigotes. J. Exp. Med. 161:1196-1212.

26. Joiner, K. A., C. H. Hammer, E. J. Brown, R. J. Cole, and M. M. Frank. 1982. Studies on the mechanism of bacterial resistance to complement-mediated killing. I. Terminal complement components are deposited and released from Salmonella minnesota S218 without causing bacterial death. J. Exp. Med. 155:797-808.

27. Inganäs, M., S. G. O. Johansson, and H. H. Bennich. 1980. Interaction of human polyclonal IgE and IgG from different species with protein A from Staphylococcus aureus: demonstration of protein-A-reactive sites located in the $\mathrm{Fab}_{2}^{\prime}$ fragment of human IgG. Scand. J. Immunol. 12:23-31.

28. Hjelm, H. 1975. Isolation of IgG3 from normal sera and from a patient with multiple myelomatosis by using protein A-Sepharose 4B. Scand. J. Immunol. 4:633-639.

29. Joiner, K., K. Warren, C. H. Hammer, and M. Frank. 1985.
Bactericidal but not non-bactericidal C5b-9 is associated with distinctive outer membrane proteins in Neisseria gonorrhoeae. J. Immunol. 134: 1920-1925.

30. Tramont, E. C., J. C. Sadoff, and M. S. Artenstein. 1974. Crossreactivity of Neisseria gonorrhoeae and Neisseria meningitidis and the nature of antigens involved in the bactericidal reaction. J. Infect. Dis. 130:240-247.

31. Glynn, A. A., and M. E. Ward. 1970. Nature and heterogeneity of the antigens of Neisseria gonorrhoeae involved in the serum bactericidal reaction. Infect. Immun. 2:162-168.

32. Rice, P. A., M. R. Tam, and M. S. Blake. 1985. IgG antibodies in normal human serum (NHS) directed against PIII block killing of serum-resistant Neisseria gonorrhoeae. In The Pathogenic Neisseriaceae: Proceedings of the Fourth International Symposium. G. K. Schoolnik, G. Brooks, S. Falco, C. Frasch, J. Knapp, A. McCutchan, and S. Morse, editors. American Society for Microbiology, Washington, DC. In press.

33. Lammel, C. J., R. L. Sweet, P. A. Rice, J. S. Knapp, G. K. Schoolnik, D. C. Heilbron, and G. F. Brooks. 1985. Antibody-antigen specificity in the immune response to gonococcal infection. J. Infect. Dis. In press.

34. O'Brien, J. P., D. L. Goldenberg, and P. A. Rice. 1983. Disseminated gonococcal infection: a prospective analysis of 49 patients and a review of pathophysiology and immune mechanisms. Medicine (Baltimore). 62:395-406.

35. Hess, E. V., D. K. Hunter, and M. Ziff. 1965. Gonococcal antibodies in acute arthritis. J. Am. Med. Assoc. 191:531-534.

36. Sarafian, S. K., M. R. Tam, and S. A. Morse. 1983. Gonococcal protein I-specific opsonic IgG in normal human serum. J. Infect. Dis. 148:1025-1032.

37. Leith, D. K., and S. A. Morse. 1980. Cross-linking analysis of Neisseria gonorrhoeae outer membrane proteins. J. Bacteriol. 143:182187.

38. McDade, R. L., Jr., and K. H. Johnston. 1980. Characterization of serologically dominant outer membrane proteins of Neisseria gonorrhoeae. J. Bacteriol. 141:1183-1191.

39. Hitchcock, P. J. 1984. Analyses of gonococcal lipopolysaccharide in whole-cell lysates by sodium dodecyl sulfate-polyacrylamide gel electrophoresis: stable association of lipopolysaccharide with the major outer membrane proteins (protein I) of Neisseria gonorrhoeae. Infect. Immun. 46:202-212.

40. Densen, P., L. A. MacKeen, and R. A. Clark. 1982. Dissemination of gonococcal infection is associated with delayed stimulation of complement-dependent neutrophil chemotaxis in vitro. Infect. Immun. 38: 563-572.

41. Ratnoff, W. P., D. T. Fearon, and K. F. Austen. 1983. The role of antibody in the activation of the alternative complement pathway. Spring Seminars in Immunopathology. 6:361-372. 